\title{
DISTRIBUSI TARGET STRENGTH IKAN DEMERSAL BERDASARKAN DETEKSI HIDROAKUSTIK DI PERAIRAN TELUK YOUTEFA, KOTA JAYAPURA
}

\section{DISTRIBUTION OF DEMERSAL FISH TARGET STRENGTH BASED ON HYDROACOUSTIC DETECTION IN YOUTEFA BAY, JAYAPURA COASTAL CITY}

\author{
Sri Pujiyati ${ }^{1}$, Baigo Hamuna ${ }^{2,3}$, Lisiard Dimara ${ }^{2,3}$, \& Nyoman Metta N. Natih ${ }^{1}$ \\ ${ }^{1}$ Departemen Ilmu dan Teknologi Kelautan, Fakultas Perikanan dan Ilmu Kelautan, Institut Pertanian Bogor \\ J1. Lingkar Kampus IPB, Dramaga, Bogor, Jawa Barat 16680 \\ ${ }^{2}$ Jurusan Ilmu Kelautan dan Perikanan, Fakultas Matematika dan Ilmu Pengetahuan Alam, Universitas Cenderawasih \\ Jl. Kamp Wolker, Kampus Baru Uncen, Kota Jayapura, Papua 99351 \\ ${ }^{3}$ Pusat Studi Sumberdaya Kelautan dan Perikanan, Universitas Cenderawasih \\ J1. Kamp Wolker, Kampus Baru Uncen, Kota Jayapura, Papua 99351 \\ e-mail : bhamuna@yahoo.com.sg
}

Diterima tanggal: 9 Oktober 2018 ; diterima setelah perbaikan: 16 November 2020 ; Disetujui tanggal: 12 Desember 2020 DOI: http://dx.doi.org/10.15578/jkn.v15i3.7181

\begin{abstract}
ABSTRAK
Teluk Youtefa merupakan perairan yang potensial untuk penangkapan ikan demersal, terutama oleh nelayan lokal di sekitar Teluk Youtefa. Survei hidroakustik dilakukan untuk mengetahui distribusi target strength (TS) dan menduga ukuran panjang ikan demersal di perairan Teluk Youtefa. Perekaman data hidroakustik dilakukan sepanjang cruise track dengan menggunakan echosounder single beam SIMRAD EK-15 frekuensi $200 \mathrm{kHz}$. Analisis data menggunakan software Echoview 4.8, dengan threshold antara -34 sampai -70 dB dan ESDU (Elementary Sampling Distance Unit) adalah 100 ping. Ikan demersal pada penelitian ini merupakan ikan yang terdeteksi pada jarak maksimum $3 \mathrm{~m}$ dari dasar perairan. Hasil penelitian menujukkan bahwa ikan demersal yang terdeteksi sebanyak 27 schooling yang tersebar pada kedalaman 3,24 sampai 33,44 m. Ikan demersal yang terdeteksi dominan pada kedalaman maksimum $10 \mathrm{~m}$ sebanyak 21 schooling. Nilai TS rata-rata ikan demersal berkisar antara $-69,58$ sampai $-45,87 \mathrm{~dB}$. Berdasakan nilai TS yang diperoleh, ikan demersal di perairan Teluk Youtefa didominasi kelompok ikan berukuran kecil. Distribusi ikan demersal di perairan Teluk Youtefa sangat dipengaruhi oleh kedalaman perairan dan tipe substrat dasar perairan.
\end{abstract}

Kata kunci: Target strength, ikan demersal, hidroakustik, Teluk Youtefa, SIMRAD EK-15.

\section{ABSTRACT}

The Youtefa Bay are potential waters for demersal fishing, especially by local fishermen around the Youtefa Bay. Hydroacoustic surveys was conducted to determine the distribution of target strength (TS) and estimate the length size of demersal fish in the Youtefa Bay. Hydroacoustic data recording was conducted along the cruise track using a SIMRAD EK15 single beam echosounder with frequency of $200 \mathrm{KHz}$. The data analysis using Echoview 4.0 software with threshold -34 to $-70 \mathrm{~dB}$ and the ESDU (Elementary Sampling Distance Unit) of 100 pings. Demersal fish in this study were fish detected at a maximum distance of $3 \mathrm{~m}$ from the seabed. The results showed that 27 detected demersal fish schooling were spread at depths of 3.24 to $33.44 \mathrm{~m}$. The demersal fish were detected dominant at a maximum depth of $10 \mathrm{~m}$ as many as 21 schooling. The average TS of demersal fish ranged from -69.58 to -45.87 dB. Based on the TS value, demersal fish in Youtefa Bay are dominated by small fish. The distribution of demersal fish in the Youtefa Bay is influenced by the depth of waters and the substrate type of the seabed.

Keywords: Target strength, demersal fish, hydroacoustic, Youtefa Bay, SIMRAD EK-15. 


\section{PENDAHULUAN}

Sumberdaya ikan demersal merupakan jenis ikan yang hidup di dasar atau dekat dasar perairan dan sebagian besar dari siklus hidupnya berada di dasar atau sekitar dasar perairan (Wiadnyana et al., 2010). Sumberdaya ikan demersal di perairan Teluk Youtefa sebagai sumberdaya yang dapat pulih masih sangat menjanjikan dan apabila dieksploitasi secara optimal akan memberikan manfaat yang berkelanjutan bagi nelayan lokal. Perairan Teluk Youtefa merupakan perairan yang potensial untuk penangkapan ikan demersal di Kota Jayapura. Tingginya sumberdaya ikan demersal di perairan Teluk Youtefa tidak diimbangi dengan informasi yang cepat dan akurat tentang dimana lokasi penangkapan ikan demersal potensial, sehingga nelayan lokal yang sering melakukan aktivitas penangkapan ikan di perairan Teluk Youtefa belum dapat memanfaatkan potensi sumberdaya tersebut secara optimal.

Ketersediaan data mengenai distribusi sumberdaya ikan demersal yang akurat dan dapat dipercaya merupakan informasi dasar yang sangat penting dalam upaya pemanfaatan dan pengelolaan perikanan demersal (Blaber et al., 1994; Simbolon et al., 2015). Salah satu metode yang dapat digunakan untuk mengetahui distribusi ikan demersal perairan adalah dengan memanfaatkan teknologi hidroakustik. Teknologi hidroakustik merupakan teknologi yang memanfaatkan pencarian bawah laut dengan suara yang kuat untuk mendeteksi dan mengamati parameter fisik dan biologi dengan mengukur intensitas echo yang dipantulkan. Teknologi hidroakustik telah banyak diimplementasikan untuk menduga distribusi dan kelimpahan ikan di perairan laut dan perairan tawar (Simmonds \& MacLennan, 2005).

Berbagai penelitian telah memanfaatkan teknologi hidroakustik untuk menganalisis, mengkaji dan pendugaan sumberdaya hayati (Priatna \& Wijopriyono, 2011; Moniharapon et al., 2014; Achmadi et al., 2014; Aisyah et al., 2015; Pujiyati et al., 2016; Nurulludin et al., 2016; Mamun et al., 2017) dan dapat diimplementasikan untuk analisis dan mengkaji sumberdaya non-hayati (Fahrulian et al., 2016; Dillenia \& Troa, 2016; Lubis et al., 2017; Hamuna et al., 2018a; 2018b) di perairan Indonesia. Pada bidang perikanan, teknologi hidroakustik sangat berperan dalam peranan yang besar di dalam industri penangkapan ikan dan penilaian ketersediaan stok sumberdaya ikan (Widodo, 1989; Mamun et al., 2017). Teknologi hidroakustik juga dapat dikombinasikan dengan metode lain, seperti jaring $t r a w l$ sebagai upaya dalam meningkatkan akurasi perhitungan stok sumberdaya ikan (Priatna et al., 2014). Pemanfaatan teknologi hidroakustik memiliki tingkat akurasi yang tinggi dalam menduga potensi sumberdaya ikan serta dapat dijadikan sebagai rujukan untuk kesesuaian akurasi dengan data hasil tangkapan yang bersumber dari data statistik perikanan (Fauziyah et al., 2010). Untuk menilai dan menduga stok sumberdaya ikan secara hidroakustik, target strength (TS) merupakan faktor yang sangat penting untuk diketahui. TS merupakan ukuran logaritmik dari energi yang dihasilkan (insiden) yang dipantulkan kembali oleh target (Simmonds \& MacLennan, 2005). Keakuratan informasi nilai TS merupakan parameter kunci yang menentukan keakuratan perkiraan kelimpahan ikan (Kim et al., 2018).

Bagi nelayan, teknologi hidroakustik merupakan teknologi yang sangat mahal, apalagi harus digunakan oleh nelayan-nelayan kecil untuk pencarian lokasi penangkapan ikan dan menghitung berapa jumlah tangkapan secara cepat dan akurat (Manik, 2014). Oleh karena itu, mengingat berbagai keunggulan teknologi hidroakustik dalam pendugaan distribusi sumberdaya ikan dan pentingnya pendugaan nilai TS ikan, maka penelitian ini dilakukan untuk mengimplementasikan teknologi hidroakustik untuk menduga distribusi TS ikan demersal dan menduga ukuran ikan demersal di perairan Teluk Youtefa, Kota Jayapura, Papua. Hasil penelitian ini diharapkan dapat memberikan informasi tentang potensi dan distribusi ikan demersal, serta lokasi potensial untuk penangkapan ikan demersal di perairan Teluk Youtefa sehingga dapat membantu nelayan-nelayan lokal Papua yang melakukan aktivitas penangkapan ikan demersal di perairan Teluk Youtefa agar dapat meningkatkan hasil tangkapan ikan dan pendapatan ekonomi.

\section{BAHAN DAN METODE}

\section{Lokasi Penelitian}

Penelitian dilaksanakan pada April 2017 yang berlokasi di perairan Teluk Youtefa, Kota Jayapura, Papua. Perekaman data hidroakustik dilakukan dalam bentuk cruise track sepanjang 12,51 km (Gambar 1). Penentuan cruise track pada penelitian ini disesuaikan dengan kondisi perairan yang dangkal di bagian tengah dan timur Teluk Youtefa (kedalaman 0 sampai $1 \mathrm{~m}$ pada saat surut terendah) dan terdapat jaring nelayan yang terpasang di tengah Teluk Youtefa, sehingga tidak dapat dilakukan survei sesuai metode dalam desain survei hidroakustik. 


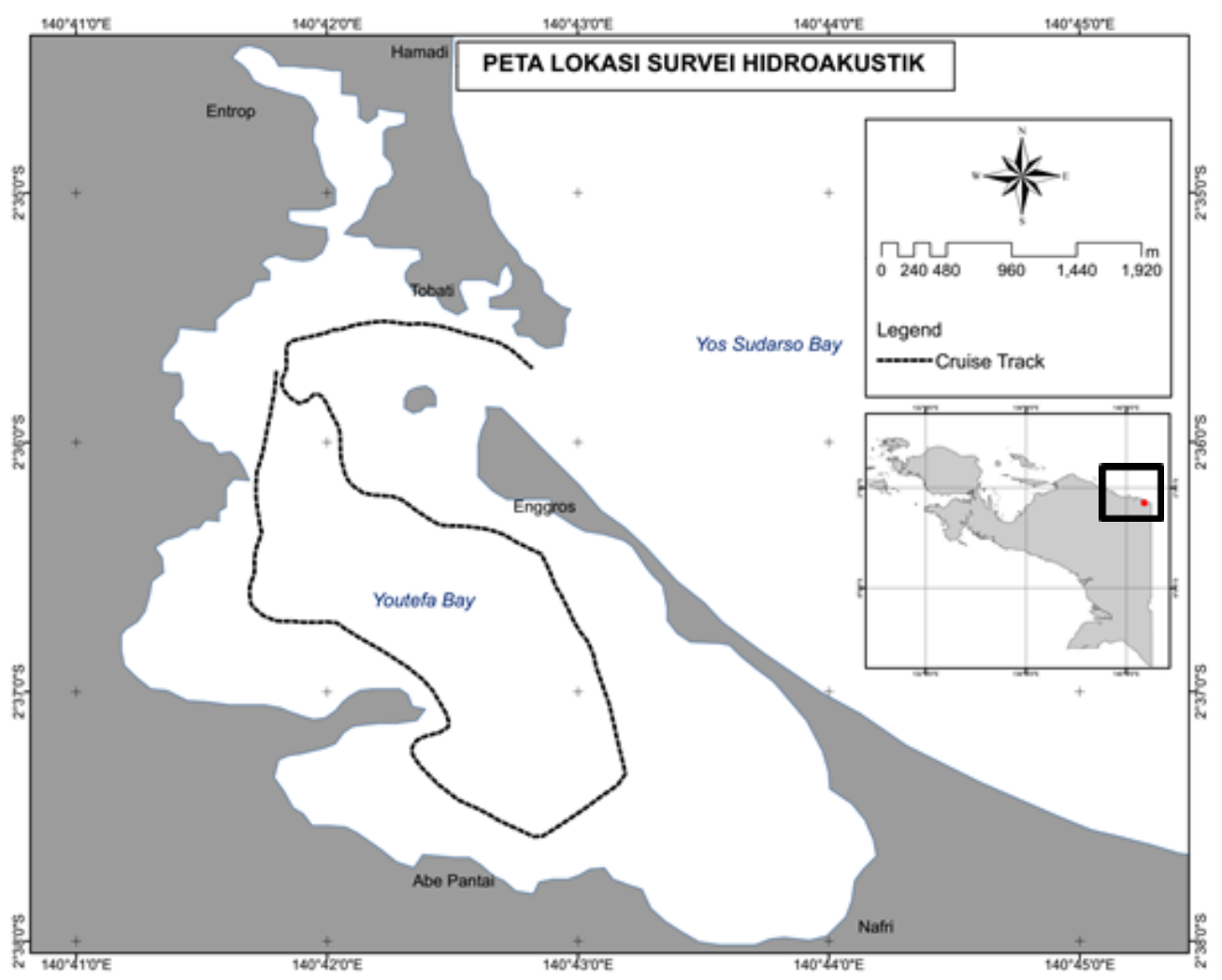

Gambar 1. Peta cruise track survei hidroakustik di perairan Teluk Youtefa. Figure 1. Map of cruise track hydroacoustic survey in Youtefa Bay.

\section{Akuisisi Data Hidroakustik}

Peralatan utama yang digunakan pada penelitian ini meliputi single beam echosounder SIMRAD EK-15 yang dioperasikan pada frekuensi $200 \mathrm{KHz}$. Spesifikasi dan setingan parameter selama perekaman data hidroakustik disajikan dalam Tabel 1. Peralatan penunjang lain yang digunakan pada penelitian ini antara lain laptop, Global Positioning System (GPS) dan kapal nelayan. Akuisisi data hidroakustik dilakukan terus-menerus selama periode pelayaran dengan kecepatan kapal maksimum 4-5 knot.

\section{Pengolahan dan Analisis Data}

Perangkat lunak yang digunakan untuk pengolahan data antara lain software Echoview 4.8 untuk pengolahan data hasil rekaman hidroakustik dan Microsoft Excel untuk tabulasi data hasil integrasi. Hasil perekaman data hidroakustik diperoleh sebanyak 15 file raw data (data mentah hasil survei hidroakustik). Pada pengolahan data hydroacoustic, elementary sampling distance unit (ESDU) yang digunakan adalah 100 ping (Mello \& Rose, 2009), sehingga seluruh data hidroakustik yang diperoleh berupa data echogram terbagi menjadi 320 ESDU. Untuk mendeteksi ikan dari hasil perekaman hidroakustik, pengolahan data menggunakan minimum threshold $-70 \mathrm{~dB}$ dan maksimum -34 dB (Manik \& Nurkomala, 2016; Park et al., 2016). Mengingat habitat ikan demersal yang berada di dekat dasar perairan, maka analisis data terfokus pada satu strata kedalaman, yaitu $3 \mathrm{~m}$ dari dasar perairan (Fahmi, 2008). Sedangkan batas dasar perairan ditambahkan $0,12 \mathrm{~m}(\mathrm{c} \tau / 2 ; \mathrm{c}=$ kecepatan suara; $\tau=$ panjang pulsa) di atas garis dasar perairan yang terdeteksi untuk menghindari masuknya echo dari dasar perairan dalam mengestimasi ikan demersal.

Data yang diolah merupakan Matriks Data Akustik (MDA), yaitu matriks data akustik back-scattering volume (SV) dari schooling ikan. Apabila dalam satu ESDU terdapat lebih dari satu schooling ikan demersal, maka perhitungan yang bersatuan $\mathrm{dB}$ harus dikonversi ke nilai linier dan sebaliknya. Hasil keluaran analisis berupa data SV yang selanjutnya digunakan untuk memperoleh nilai TS hasil integrasi menggunakan persamaan (Echoview) yang diacu dalam Achmadi et al. (2014) sebagai berikut:

$T_{s}=S_{v} / \rho$

$T S=10 \log (T S)$

Nilai Sv dan $\rho$ pada persamaan (1) dapat diperoleh dengan menggunakan persamaan berikut: 
$S V=10 \log (S v)$

$S v=10^{S V / 10}$

$\rho=n / v$

Salah satu faktor yang sangat berpengaruh terhadap nilai TS adalah ukuran ikan. Ukuran panjang ikan (L) berhubungan linear dengan scattering cross section $(\sigma b s=a L b)$. Untuk mengkonversi nilai target strength ikan demersal menjadi ukuran panjang ikan (L) digunakan persamaan berikut (Hjellvik et al., 2003):

$T S=20 \log L-68$

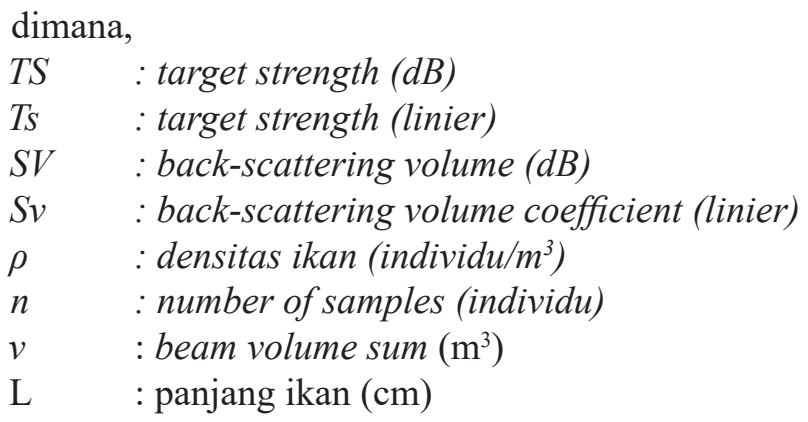

\section{HASIL DAN PEMBAHASAN}

Distribusi TS Ikan Demersal di Perairan Teluk Youtefa Identifikasi spesies atau jenis ikan yang terdeteksi pada echogram merupakan identifikasi yang bersifat subjektif (Coetzee, 2000). Secara hidroakustik, ikan yang terlihat pada echogram menggambarkan agregasi (schooling) ikan bukan secara individual. Selama survei untuk perekaman data hidroakustik di perairan Teluk Youtefa, schooling ikan demersal yang terdeteksi sebanyak 27 schooling. Berdasarkan batas integrasi $3 \mathrm{~m}$ dari dasar perairan, schooling ikan demersal terdeteksi berada pada jarak rata-rata 0,26 sampai

Tabel 1. Konfigurasi instrumen selama survei hidroakustik Table 1. Instrument configuration during hydroacoustic survey

\begin{tabular}{ll}
\hline Parameter & Nilai \\
\hline Tipe transduser & Single beam \\
Frekuensi (kHz) & 200 \\
Power transmit (watt) & 50 \\
Lebar beam (deg) & 26 \\
Kedalaman transduser (m) & 0,5 \\
Ping rate (Hz) & $>40$ \\
Panjang pulsa (ms) & 0,160 \\
Durasi pulsa (ms) & 0,128 \\
Kecepatan suara (ms-1) & $1.545,87$ \\
Koeficien absorpsi $(\mathrm{dBm}-1)$ & 0,01872 \\
Transducer gain $(\mathrm{dB})$ & 14,20 \\
\hline
\end{tabular}

2,93 $\mathrm{m}$ di atas permukaan dasar perairan dan dominan terdeteksi berada pada jarak kurang dari 2 meter di atas permukaan dasar perairan dengan ketinggian schooling antara 0,49 sampai $1,70 \mathrm{~m}$. Hal ini menunjukkan bahwa ikan demersal yang terdeteksi pada penelitian ini dominan berada dekat dasar perairan.

Berdasarkan hasil analisis, nilai TS rata-rata ikan demersal di perairan Teluk Youtefa yang terdeteksi pada setiap ESDU yaitu antara $-69,58$ sampai $-45,87$ dB. Nilai TS ikan demersal di perairan Teluk Youtefa didominasi oleh kisaran TS yang rendah, yaitu $-69,58$ sampai $-60,00 \mathrm{~dB}$. Berdasarkan nilai TS dominan tersebut, ikan demersal yang terdeteksi didominasi oleh ikan demersal yang berukuran kecil (Manik \& Nurkomala, 2016). Hasil yang diperoleh pada penelitian ini tidak berbeda jauh dengan hasil pengamatan di lapangan bahwa hasil tangkapan ikan demersal di perairan Teluk Youtefa didominasi oleh ikan yang berukuran kecil. Hal ini menunjukan bahwa ikan demersal yang berada di Teluk Youtefa adalah ikan demersal berukuran kecil.

Secara spasial, ikan demersal dominan terdistribusi pada perairan di sekitar Kampung Enggros hingga Kampung Abe Pantai. Kondisi ini disebabkan karena terdapatnya vegetasi lamun yang merupakan habitat yang baik untuk ikan-ikan demersal. Vegetasi lamun sebagai habitat ikan memberikan dukungan terhadap kelimpahan ikan (Gillanders, 2006). Faktor pemijahan juga menjadi sifat beberapa ikan yang membutuhkan vegetasi (berasosiasi dengan tanaman air) atau substrat tertentu.

Berdasarkan hasil penelitian Tebaiy et al. (2014), terdapat sebanyak 79 spesies ikan dari 36 famili yang termasuk ke dalam 10 ordo ditemukan di Teluk Youtefa. Jenis $S$. canaliculatus, A. strigatus, $A$. ceramensis, S. fuscescens, P. barberinus, dan S. lineata adalah jenis ikan demersal yang dominan ditemukan di perairan Teluk Youtefa. Habitat lamun di perairan Teluk Youtefa menjadi tempat yang ideal bagi enam jenis ikan tersebut sebagai tempat asuhan, pembesaran dan tempat mencari makanan. Terdapat hubungan yang signifikan antara kelimpahan ikan demersal dan habitatnya, dimana tipe habitat merupakan faktor yang sangat penting dan berpengaruh terhadap distribusi ikan demersal (van der Kooij et al., 2011).

Ikan demersal di perairan Teluk Youtefa cenderung terkonsentrasi pada perairan yang dangkal pada kisaran kedalaman hingga $10 \mathrm{~m}$ dengan kisaran nilai TS yang relatif rendah, yaitu antara -70 sampai -60 
Tabel 2. Distribusi TS rata-rata ikan demersal berdasarkan strata kedalaman perairan

Table 2. Distribution of demersal fish TS based on depth strata

\begin{tabular}{llllll}
\hline TS (dB) & \multicolumn{6}{c}{ Kedalaman dasar perairan (m) } & $\boldsymbol{\Sigma}$ \\
& $\mathbf{0 - 1 0}$ & $\mathbf{1 0 - 2 0}$ & $\mathbf{2 0 - 3 0}$ & $\mathbf{> 3 0}$ & \\
\hline$(-45)-(-40)$ & 1 & 0 & 0 & 0 & 1 \\
$(-50)-(-45)$ & 0 & 0 & 0 & 1 & 1 \\
$(-55)-(-50)$ & 1 & 0 & 1 & 0 & 2 \\
$(-60)-(-55)$ & 2 & 2 & 0 & 0 & 4 \\
$(-65)-(-60)$ & 7 & 2 & 0 & 0 & 9 \\
$(-70)-(-65)$ & 10 & 0 & 0 & 0 & 10 \\
\hline$\Sigma$ & & & 1 & 1 & 27 \\
\hline
\end{tabular}

Sumber: Analisis Data, 2018

dB (Tabel 2). Adapun pada perairan yang lebih dalam (kedalaman $>20 \mathrm{~m}$ ) hanya ditemukan 2 schooling ikan demersal dengan nilai TS yang cukup tinggi $(-54,29$ dB dan $-47,36$ dB). Hasil beberapa survei hidroakustik ikan demersal menunjukkan hasil yang sama dengan penelitian ini, dimana schooling ikan demersal lebih banyak terdeteksi di perairan pantai yang relatif dangkal yang didominasi oleh nilai TS yang rendah (Fahmi, 2008; Pujiyati, 2008). Distribusi nilai TS ikan akan semakin besar dengan meningkatnya kedalaman perairan, namun dalam jumlah yang semakin berkurang (Rajali et al., 1998; Perangin-angin et al., 2016).

Terdapat hubungan antara pola distribusi ikan demersal dengan faktor-faktor fisik perairan seperti kedalaman perairan (Rainer \& Munro, 1982; Ridho et al., 2004; Suman, 2011; Zintzen et al., 2012). Kedalaman perairan sangat berpengaruh terhadap distribusi ikan demersal (Macpherson \& Duarte, 1991). Peningkatan kedalaman perairan akan berpengaruh terhadap kelimpahan dan kekayaan spesies ikan demersal, dimana kekayaan spesies ikan demersal lebih tinggi di perairan dangkal (Labropoulou \& Papaconstantinou, 2004; Zintzen et al., 2012).

\section{Dugaan Ukuran Ikan Demersal yang Terdeteksi}

TS ikan berhubungan signifikan dengan ukuran panjang ikan (Simmonds \& MacLennan, 2005; Manik, 2009; Reine et al., 2010; Kim et al., 2018). Berdasarkan nilai TS, ukuran panjang ikan demersal yang terdeteksi di perairan Teluk Youtefa berkisar 0,83 sampai $12,78 \mathrm{~cm}$. Gambar 2 merupakan perbandingan TS ikan demersal dengan ukuran panjang ikan, dimana menunjukan semakin panjang ukuran ikan akan menghasilkan nilai TS yang lebih besar dan sebaliknya. Berdasarkan kelompok ukuran panjang ikan, ukuran panjang ikan demersal didominasi oleh kelompok ukuran kecil dengan panjang maksimal yang dominan adalah $4 \mathrm{~cm}$ dan dominan ditemukan pada perairan yang relatif lebih dangkal (Gambar 3).

Berdasarkan Rajali et al. (1998), Pujiyati et al. (2007), Manik \& Nurkomala (2016), dan Peranginangin et al. (2016) bahwa distribusi nilai TS ikan akan semakin besar pada kedalaman perairan yang semakin tinggi. Hasil penelitian Manik \& Nurkomala (2016) menemukan bahwa nilai TS rata-rata pada selang kedalaman perairan 2-11 m didominasi oleh kelompok TS kecil (-70 sampai $-61 \mathrm{~dB}$ ) dan nilai TS rata-rata bertambah tinggi pada selang kedalaman perairan 11-21 m dan 21-31 m yang didominasi oleh kelompok TS sedang (-61 sampai $-49 \mathrm{~dB}$ ). Selanjutnya hasil penelitian Perangin-angin et al. (2016) bahwa kedalaman perairan 20-30 m didominasi ikan demersal berukuran kecil pada selang nilai TS -60 sampai -48 $\mathrm{dB}$, ikan demersal berukuran sedang pada selang nilai TS -48 sampai $-40 \mathrm{~dB}$ mendominasi perairan dengan selang kedalaman dasar perairan $30-40 \mathrm{~m}$,

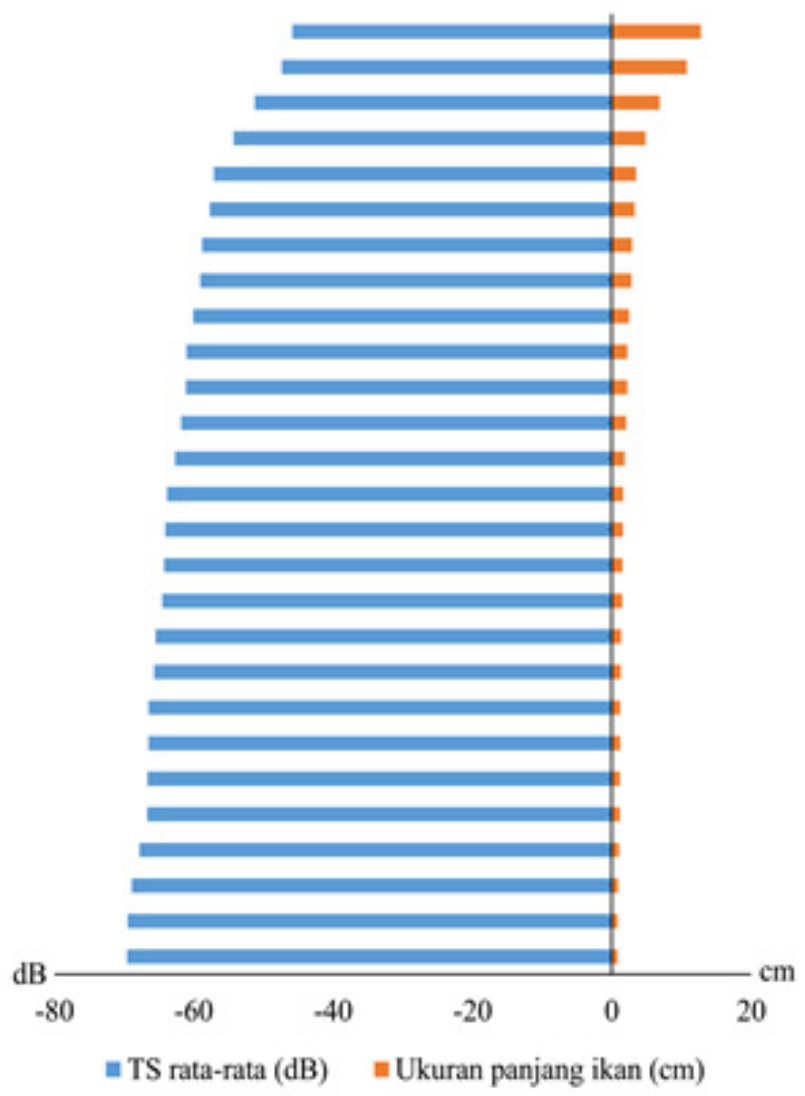

Gambar 2. Perbandingan TS dan ukuran panjang ikan.

Figure 2. Comparison of TS and fish length. Sumber: Analisis Data, 2018 


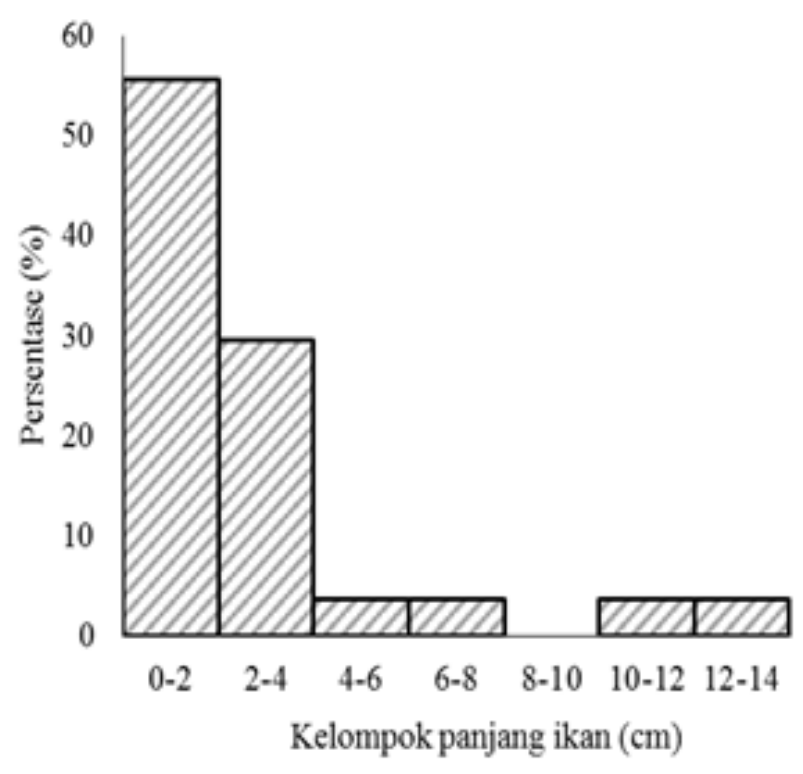

Gambar 3. Komposisi dugaan ukuran panjang ikan berdasarkan nilai TS di perairan Teluk Youtefa.

Figure 3. Composition of fish length based on TS value in the Youtefa Bay coastal waters.

Sumber: Analisis Data, 2018

40-50 m, dan 50-60 m, sedangkan ikan demersal yang berukuran besar pada selang nilai TS - 40 sampai $-34 \mathrm{~dB}$ mendominasi perairan dengan selang kedalaman dasar perairan 50-60 m dan 60-70 m. Hal ini menunjukan bahwa semakin dalam suatu perairan, maka ukuran ikan yang terdeteksi akan semakin besar.

Gambar 4 menunjukan hubungan korelasi antara ukuran ikan demersal berdasarkan nilai TS yang terdeteksi secara hidroakustik dengan kedalaman perairan. Hasil penelitian ini menunjukan bahwa hubungan antara ukuran ikan demersal dengan kedalaman perairan bersifat linier positif, akan tetapi hubungan tersebut tidak terlalu kuat. Nilai korelasi hubungan tersebut cukup rendah, yaitu nilai koefisien determinasi $\left(\mathrm{r}^{2}\right)$ adalah 0,28 dan nilai koefosien korelasi (r) adalah 0,53 . Berdasarkan nilai koefisien determinasi tersebut bahwa distribusi ukuran ikan demersal yang terdeteksi dipengaruhi oleh kedalaman perairan sebesar $28 \%$ sedangkan $72 \%$ lainnya tidak dapat dijelaskan oleh pengaruh kedalaman perairan atau $72 \%$ distribusi ukuran ikan demersal dipengaruhi oleh faktor lainnya. Rendahnya hubungan korelasi tersebut diduga karena ikan demersal yang terdeteksi pada penelitian ini merupakan ikan demersal multi spesies, dimana distribusi secara vertikal berbeda antar spesies ikan demersal. Hal ini ditunjukan pada hasil deteksi hidroakustik bahwa pada kedalaman kurang dari $10 \mathrm{~m}$, selain didominassi oleh ikan demersal berukuran kecil juga terdeteksi ikan demersal berukuran lebih besar. Hasil penelitian Wedjatmiko et al. (2007), sebaran ikan petek (Leiognathidae) berbeda-beda berdasarkan strata kedalaman, diamana pada kedalaman $<10$ m dan 10-20 $\mathrm{m}$ didominasi oleh Leioghnatus splendens, kedalaman 21-40 m didominasi oleh L. bindus, kedalaman 41-50 $\mathrm{m}$ didominasi oleh Gazza minuta, dan pada perairan lebih dalam (> $50 \mathrm{~m}$ ) didominasi oleh L. leusiscus.

Beberapa hasil penelitian lain menunjukan bahwa distribusi vertikal ikan demersal dipengaruhi oleh berbagai faktor selain kedalaman perairan. Tipe substrat dasar perairan juga sangat berpengaruh terhadap distribusi ikan-ikan demersal (Pujiyati, 2008, Akbar et al., 2013; van der Kooij et al., 2011) dan menunjukkan pola distribusi yang berbeda pada beberapa spesies ikan demersal (Pujiyati, 2008). Adanya perbedaan dasar perairan sebagai habitat ikan demersal dapat menyebabkan perbedaan komposisi jenis ikan demersal (Suman, 2011). Ketersediaan makrozoobentos pada substrat dasar perairan juga berpengaruh terhadap distribusi ikan demersal, dimana makrozoobentos tersebut berperan sebagai makanan bagi ikan demersal (Nugraheni, 2011). Selain itu, faktor oseanografi perairan seperti salinitas dan suhu perairan sangat berpengaruh terhadap distribusi sumberdaya ikan demersal (Ridho et al., 2004).

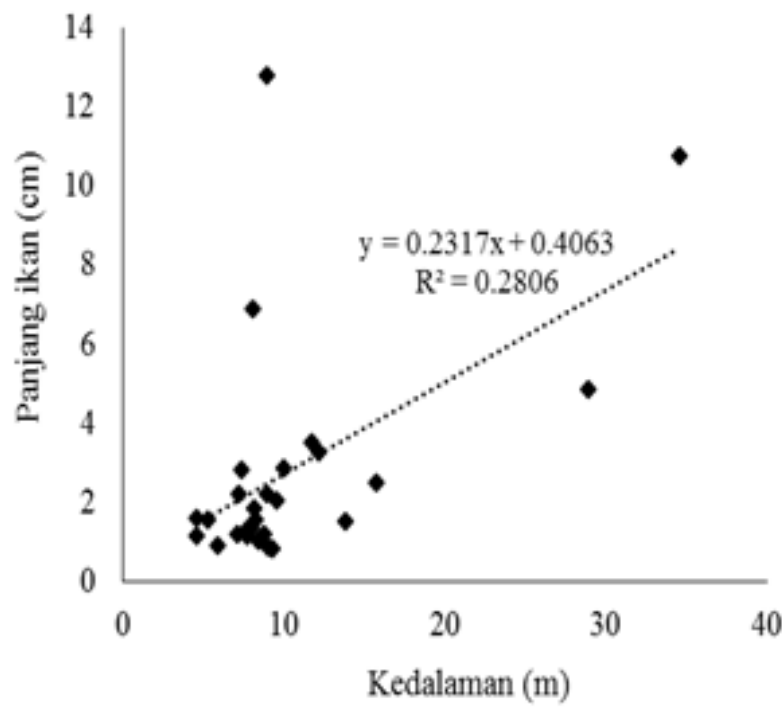

Gambar 4. Grafik hubungan antara ukuran panjang ikan berdasarkan nilai TS dan kedalaman perairan Teluk Youtefa.

Figure 4. Graph of the relationship between fish length based on TS value and waters depth of Youtefa Bay. Sumber: Analisis Data, 2018 


\section{KESIMPULAN DAN SARAN}

Potensi ikan demersal di perairan Teluk Youtefa, Kota Jayapura berdasarkan hasil deteksi hidroakustik cukup potensial. Lokasi potensial adalah di sekitar perairan pesisir Kampung Enggros dan Abe Pantai, dimana pada kedua lokasi tersebut banyak terdeteksi schooling ikan demersal. Distribusi ikan demersal sangat dipengaruhi oleh tipe substrat dasar dan kedalaman perairan. Dari 27 schooling ikan demersal yang terdeteksi, sebagian besar terkonsentrasi pada perairan dangkal dengan kedalaman maksimal $10 \mathrm{~m}$ yang didominasi oleh ikan demersal berukuran kecil hingga sedang. Schooling ikan demersal banyak terdeteksi pada lokasi tumbuhnya vegetasi lamun pada perairan dangkal.

Informasi potensi, distribusi dan lokasi potensial untuk penangkapan ikan demersal di perairan Teluk Youtefa yang diperoleh pada penelitian ini merupakan informasi dasar yang sangat penting dalam upaya pemanfaatan potensi perikanan demersal di perairan Teluk Youtefa, terutama untuk nelayan lokal Papua yang sebagian besar merupakan nelayan tradisional sehingga dapat meningkatkan hasil tangkapan ikan dan pendapatan ekonominya.

\section{UCAPAN TERIMA KASIH}

Artikel ini merupakan bagian dari hasil Penelitian Kerjasama Antar Perguruan Tinggi (PEKERTI atau PKPT) tahun 2017-2018, oleh karena itu penulis ingin menyampaikan terima kasih kepada Direktorat Riset dan Pengabdian Masyarakat, Kementerian Riset, Teknologi dan Pendidikan Tinggi (DRPMRISTEKDIKTI) yang telah membiayai penelitian ini. Analisis lanjutan dilakukan 2019-2020. Penulis juga menyampaikan terima kasih kepada Asep Mamun, S.Pi., M.Si. (Balai Penelitian Perikanan Laut, Jakarta) yang telah membantu dalam proses perekaman data hidroakustik, serta mahasiswa Jurusan Ilmu Kelautan dan Perikanan, Universitas Cenderawasih yang telah membantu dalam proses pengambilan data di lapangan.

\section{DAFTAR PUSTAKA}

Achmadi, A., Hestirianoto, T., \& Manik, H. M. (2014). Deteksi schooling ikan pelagis dengan metode hidroakustik di perairan Teluk Palu, Sulawesi Tengah. Jurnal Teknologi Perikanan dan Kelautan, 5(2), 131-139.

Aisyah, Hestirianoto, T., \& Pujiyati, S. (2015). Sebaran spasial volume backscattering strength ikan pelagis di Danau Ranau, Sumatera Selatan. Jurnal Teknologi Perikanan dan Kelautan, 6(1), 11-20.

Akbar, H., Pujiyati, S., \& Natsir, M. (2013). Hubungan tipe dasar perairan dengan distribusi ikan demersal di perairan Pangkajene Sulawesi Selatan 2011. Jurnal Teknologi Perikanan dan Kelautan, 4(1), 31-39.

Blaber, S. J. M., Brewer, D. T., \& Harris, A. N. (1994). Distribution, biomass and community structure of demersal fishes of the Gulf of Carpentaria, Australia. Australian Journal of Marine and freshwater Research, 45(3), 375-396.

Coetzee, J. (2000). Use of a shoal analysis and patch estimation system (SHAPES) to characterize sardine schools. Aquatic Living Resource, 13(1), $1-10$.

Dillenia, I., \& Troa, R. A. (2016). Identifikasi situs kapal karam bersejarah "karang panjang" di perairan Pulau Laut Natuna. Jurnal Kelautan Nasional, 11(1), 11-20.

Fahmi, Z. (2008). Pendugaan kelimpahan dan sebaran ikan demersal dengan menggunakan metode akustik di perairan Belitung. BAWAL, 2(2), 6368.

Fahrulian, Manik, H. M., Jaya, I., \& Udrekh. (2016). Angular range analysis (ARA) and K-means clustering of multibeam echosounder data for determining sediment type. Ilmu Kelautan: Indonesia Journal of Marine Science, 21(4), 177-184.

Fauziyah, Hartoni., \& Agussalim, A. (2010). Karakteristik shoaling ikan pelagis menggunakan data akustik split beam di perairan Selat Bangka pada musim timur. Ilmu Kelautan: Indonesia Journal of Marine Science, 15(1), 17-22.

Gillanders, B. M. (2006). Seagrasses, fish and fisheries. In Larkum, A. W. D., Orth, R. J., Duarte, M., (Ed.), Seagrasses: biology, ecology and conservation (pp. 503-530). Springer: Netherlands.

Hamuna, B., Dimara, L., Pujiyati, S., \& Natih, N. M. N. (2018a). Correlation of substrate fraction percentage with acoustic backscattering strength 
from single beam echosounder detection. $A A C L$ Bioflux, 11(4), 1343-1351.

Hamuna, B., Pujiyati, S., Natih, N. M. N., \& Dimara, L. (2018b). Analisis hambur balik akustik untuk klasifikasi dan pemetaan substrat dasar perairan di Teluk Yos Sudarso, Kota Jayapura. Jurnal Ilmu dan Teknologi Kelautan Tropis, 10(2), 291300.

Hjellvik, V., Michalsen, K., Aglen, A. \& Nakken, O. (2003). An attempt at estimating the effective fishing height of the bottom trawl using acoustic survey recordings. ICES Journal of Marine Science. 60(5), 967-979.

Kim, H., Kang, D., Cho, S., Kim, M., Park, J., \& Kim, K. (2018). Acoustic target strength measurements for biomass estimation of aquaculture fish, Redlip mullet (Chelon haematocheilus). Applied Sciences, 2018(8), 1536.

Labropoulou, M. \& Papaconstantinou, C. (2004). Community structure and diversity of demersal fish assemblages: the role of fishery. Scientia Marina, 68(1), 215-226

Lubis, M. Z., Anurogo, W., Khoirunnisa, H., Irawan, S., Gustin, O. \& Roziqin, A. (2017). Using sidescan sonar instrument to characterize and map of seabed for identification target in Punggur Sea of the Riau Islands. Journal of Geoscience, Engineering, Environment, and Technology, 2(1), 1-8.

Macpherson, E., \& Duarte, C. M. (1991). Bathymetric trends in demersal fish size: is there a general relationship? Marine Ecology Progress Series, 71(2), 103-112.

Mamun, A., Priatna, A., Hidayat, T., \& Nurulludin. (2017). Distribusi dan potensi sumber daya ikan pelagis di Wilayah Pengelolaan Perikanan Negara Republik Indonesia 573 (WPP NRI 573) Samudera Hindia. Jurnal Penelitian Perikanan Indonesia, 23(1), 47-56.

Manik, H. M., \& Nurkomala, I. (2016). Pengukuran target strength dan stok ikan di perairan Pulau Pari menggunakan metode single echo detector. Marine Fisheries, 7(1), 69-81.

Manik, H. M. (2009). Measurement of acoustic reflection of tuna fish using echosounder instrument. Ilmu Kelautan: Indonesia Journal of Marine Science, 14(2), 84-88.

Manik, H. M. (2014). Teknologi akustik bawah air: solusi data perikanan laut Indonesia. Risalah Kebijakan Pertanian dan Lingkungan, 1(3), 181-186.

Mello, L. G. S., \& Rose, G. A. (2009). The acoustic dead zone: theoretical vs empirical estimates, and its effect on density measurements of semidemersal fish. ICES Journal of Marine Science, 66(6), 1364-1369.

Moniharapon, D., Jaya, I., Manik, H., Pujiyati, S., Hestirianoto, T., \& Syahailatua, A. (2014). Migrasi vertikal zooplankton di Laut Banda. Jurnal Kelautan Nasional, 9(3), 143-151.

Nugraheni, A. D. (2011). Hubungan antara distribusi ikan demersal, makrozoobentos, dan substrat di perairan Malaka. Skripsi. Departemen Ilmu dan Teknologi Kelautan: Institut Pertanian Bogor.

Nurulludin, Hidayat, T., \& Mamun, A. (2016). Kepadatan stok ikan demersal dan udang di Samudera Hindia Barat Sumatera pada musim peralihan II. Jurnal Penelitian Perikanan Indonesia, 22(3), 139-146.

Park, Y., Seo, Y. I., Oh, T. Y., Lee, K., Zhang, H., \& Kang, M. Anchovy distributional properties by time and location: using acoustic data from a primary trawl survey in the south sea of South Korea. Journal of Marine Science and Technology, 24(4), 864-875.

Perangin-angin, R., Sulistiono, Kurnia, R., Fahrudin, A. \& Suman, A. (2016). Kepadatan dan stratifikasi komposisi sumber daya ikan demersal di Laut Cina Selatan (WPP-NRI 711). Jurnal Penelitian Perikanan Indonesia, 22(3), 161-172.

Priatna, A., \& Wijopriono. (2011). Estimasi stok sumber daya ikan dengan metode hidroakustik di perairan Kabupaten Bengkalis. Jurnal Penelitian Perikanan Indonesia, 17(1), 1-10.

Priatna, A., Purbayanto, A., Simbolon, D., \& Hestirianoto, T. (2014). Kemampuan tangkap jaring trawl terhadap ikan demersal di perairan Tarakan dan sekitarnya. Jurnal Penelitian

JURNAL KELAUTAN NASIONAL, Vol. 15, No 3, Desember 2020, Hal. 165-174 
Perikanan Indonesia, 20(1), 19-30.

Pujiyati, S. (2008). Pendekatan metode hidroakustik untuk analisis keterkaitan antara tipe substrat dasar perairan dengan komunitas ikan demersal. Disertasi. Sekolah Pascasarjana: Institut Pertanian Bogor.

Pujiyati, S., Hestirianoto, T., Wulandari, P. D. \& Lubis, M. Z. (2016). Fish stock estimation by using the hydroacoustic survey method in Sikka Regency waters, Indonesia. Journal of Fisheries \& Livestock Production, 4(3), 193.

Pujiyati, S., Wijopriono, Mahiswara, Pasaribu, B. P., Jaya, I., \& Manurung, D. (2007). Estimasi hambur balik dasar perairan dan sumber daya ikan demersal menggunakan metode hidroakustik. Jurnal Penelitian Perikanan Indonesia, 13(2), 145-155.

Rainer, S. F., \& Munro, I. S. R. (1982). Demersal fish and cephalopod communities of an unexploited coastal environment in Northern Australia. Australian Journal of Marine and freshwater Research, 33(6), 1039-1055.

Rajali, H., Gambang, A. C., Hamid, I. A., Hasan, R. B., Awang, D., Shiomi, K., \& Fujiwara, S. (1998). Stock assessment by hydroacoustic method in the South China Sea Area II: Sabah, Sarawak, Brunei Darussalam. Proceedings of the SEAFDEC Technical Seminar on the Interdepartmental Collaborative Research Program in the South China Sea, Area II: Sarawak, Sabah, and Brunei Darussalam, 338-352. Kuala Lumpur, Malaysia: SEAFDEC.

Reine, K., Clarke, B., Dickerson, C., Hager, C., Balazik, M., Garmin, G., Spells, A., \& Frederickson, C. (2010). The relationship between acoustic target strength and body length for Atlantic sturgeon (Acipenser oxyrinchus oxyrinchus). ERDC TN-DOER-E27. Vicksburg, MS: U.S. Army Engineer Research and Development Center.

Ridho, M. R., Kaswadji, R. F., Jaya, I., \& Nurhakim, S. (2004). Distribusi sumberdaya ikan demersal di perairan Laut Cina Selatan. Jurnal Ilmu-Ilmu Perairan dan Perikanan Indonesia, 11(2), 123128.
Purbayanto, A. (2015). Perbandingan antara marine acoustic remote sensing dan swept area trawl dalam pendugaan densitas ikan demersal di perairan Tarakan. Jurnal Penginderaan Jauh dan Pengolahan Data Citra Digital, 12(2), 91106.

Simmonds, E. J., \& MacLennan, D. N. (2005). Fisheries acoustics: theory and practice, 2nd ed. Oxford: Blackwell Science.

Suman, A. (2011). Stok sumberdaya ikan demersal laut dalam di perairan ZEEI Samudera Hindia sebelah Selatan Jawa. Biosfera, 28(1), 1-8.

Tebaiy, S., Yulianda, F., Fahrudin, A. \& Muchsin, I. (2014). Struktur komunitas ikan pada habitat lamun di Teluk Youtefa Jayapura Papua. Jurnal Iktiologi Indonesia, 14(1), 49-65.

van der Kooij, J., Kupschus, S., \& Scott, B. E. (2011). Delineating the habitat of demersal fish assemblages with acoustic seabed technologies. ICES Journal of Marine Science, 68, 1973-1985.

Wedjatmiko, Ernawati, T., \& Sukarniaty. (2007). Komposisi jenis dan distribusi ikan petek (Leiognathidae) di perairan Selat Makassar. Jurnal Penelitian Perikanan Indonesia, 13(1), 53-60.

Wiadnyana, N. N., Badrudin, \& Aisyah. (2010). Tingkat pemanfaatan sumber daya ikan demersal di wilayah pengelolaan perikanan Laut Jawa. Jurnal Penelitian Perikanan Indonesia, 16(4), 275-283.

Widodo, J. (1989). Prinsip dasar hidroakustik perikanan. Oseana, 16(3), 81-92.

Zintzen, V., Anderson, M. J., Roberts, C. D., Harvey, E. S., Stewart, A. L., \& Struthers, C. D. (2012). Diversity and composition of demersal fishes along a depth gradient assessed by baited remote underwater stereo-video. PLOS ONE, 7(10), e48522.

Simbolon, D., Priatna, A., Hestirianoto, T. \& 
